\title{
Impact of pig slurry on soil properties, water salinization, nitrate leaching and crop yield in a four-year experiment in Central Spain
}

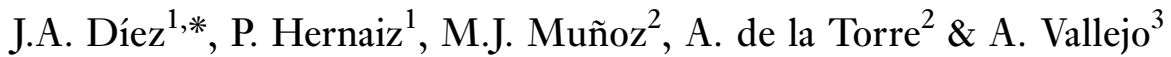

\begin{abstract}
The repeated application of pig slurry to agricultural soils may result in an accumulation of salts and a risk of aquifer pollution due to nitrate leaching and salinization. Under Mediterranean conditions, a field experiment on a sandy loam soil (Typic Xerofluvent) was performed with maize (Zea mays) in 1998, 1999 and 2001 to study the effects of applying optimal (P1) and excessive rates (P3) of pig slurry on soil salinization, nitrate leaching and groundwater pollution. The rate of pig slurry was established considering the optimal $\mathrm{N}$ rate for maize in this soil $\left(170,162\right.$ and $176 \mathrm{~kg} \mathrm{~N} \mathrm{ha}^{-1}$ for 1998,1999 and 2001, respectively). Pig slurry treatments were compared to an optimal $\mathrm{N}$ rate supplied as urea $(\mathrm{U})$ and a control treatment without $\mathrm{N}$ fertilizer ( $\mathrm{P} 0)$. The composition of the slurries showed great variability between years. Mean $\mathrm{NO}_{3}^{-}$leaching losses from 1998 to 2001 were 329, 215, 173 and $78 \mathrm{~kg} \mathrm{~N} \mathrm{ha}^{-1}$ for P3, P1, U and P0 treatments, respectively. The amount of total dissolved salts (TDS) added to the soil in slurry application between 1998 and 2001 was $2019 \mathrm{~kg} \mathrm{TDS} \mathrm{ha}^{-1}$ for the P1 treatment and $6058 \mathrm{~kg} \mathrm{TDS} \mathrm{ha}^{-1}$ for the P3 treatment. As a consequence, the electrical conductivity (EC) of the slurry-treated soils was greater than that of the control soil. The EC correlated significantly with the sodium concentration of the soil solution. Over the entire experimental period, 2653,2202 and $2110 \mathrm{~kg} \mathrm{Na} \mathrm{ha}^{-1}$ entered the aquifer from the P3, P1 and P0 treatments, respectively. The P3 treatment did not significantly increase grain production in 1999 and 2001 compared with that achieved with the optimal $\mathrm{N}$ rate treatment (P1). This behaviour shows the importance of establishing application guidelines for pig slurry that will reduce the risk of soil and groundwater pollution.
\end{abstract}

Keywords: Irrigation, leaching, maize, nitrate, pig slurry, soil salinity, aquifer pollution

\section{INTRODUCTION}

$\mathrm{T}$ he soils of Mediterranean countries are often relatively infertile, low in organic matter (frequently $<2 \%$ ), and at risk of erosion (Ferrer \& Sanz 1983). The application of livestock waste is therefore usually beneficial. As the second largest pig producer in the European Union (EU), Spain generates $2 \times 10^{10} \mathrm{~kg} \mathrm{yr}^{-1}$ of pig slurry, over half of which is used directly as fertilizer (Chávez \& Babot 2001). Given its high water content, pig slurry use is generally limited to areas close to where it was produced. Unfortunately, this use is often indiscriminate, with no regard for optimum levels of application; it can lead to serious pollution problems in areas where excess slurry is applied (European Community 1991). The emissions of ammonia $\left(\mathrm{NH}_{3}\right)$,

${ }^{1}$ Centro de Ciencias Medioambientales (CCMA, CSIC), C/Serrano 115, 28006 Madrid, Spain. ${ }^{2}$ CISA-INIA, Valdeolmos, 28130 Madrid, Spain. ${ }^{3}$ ETS Ingenieros Agrónomos, UPM, Ciudad Universitaria, 28040 Madrid, Spain.

*Corresponding author: Tel: +34 91 7452500. Fax: +34 915640800 .

E-mail: jadíez@ccma.csic.es nitrous oxide $\left(\mathrm{N}_{2} \mathrm{O}\right)$ and nitric oxide $(\mathrm{NO})$ and the leaching of nitrate $\left(\mathrm{NO}_{3}^{-}\right)$after slurry application represent serious environmental problems; slurry applications to land have also been held responsible for contamination of surface waters with coliform bacteria (Vinten et al. 2002).

Nitrate leaching is normally intensified by excessive rainfall or irrigation, as well as by use of $\mathrm{N}$ fertilization that is surplus to crop requirements (Díez et al. 1997, 2000). Recent studies have shown the importance of slurry application for optimizing maize grain production while minimizing $\mathrm{NO}_{3}^{-}$pollution (Díez et al. 2001; Al-Kaisi \& Waskom 2002). However, application guidelines are difficult to establish given the variable composition of slurries, which depend on several factors, such as age and feed of animals and different cleaning systems. The amount of available soil N (Sánchez et al. 1998), the slurry N content and the $\mathrm{N}$ requirement of the crop must be known for the optimum application rate to be estimated (Díez et al. 2000).

Large applications of liquid animal manures, which often have a high salt content due to the addition of salt to the diet, can increase soil salinity and the $\mathrm{Na}^{+}$content of 
the soil solution and groundwater. Hao \& Chang (2003) have studied this risk with cattle manure. Soil salinity is one of the most important factors reducing soil quality and productivity (Shortall \& Liebhardt 1975). Salinization usually occurs over the first few days following slurry application (Díez et al. 2001), but it decreases thereafter because of rainfall and irrigation.

Currently, the EU is attempting to deal with the problems of organic wastes by identifying the risks and benefits associated with their agricultural use (European Community 2001). These efforts also include a proposal to modify directive 86/278/EEC (Joint Research Centre 2001). If successful, this problem can be tackled on a more scientific basis.

The aim of this work was to evaluate the effects of applying optimal and excessive rates of pig slurry on soil and groundwater salinization, nitrate leaching and the yield of a maize crop, in an irrigated Mediterranean soil.

\section{MATERIALS AND METHODS}

\section{Experimental site}

The experimental site was located at La Poveda Field Station in Arganda del Rey (Madrid) $\left(40^{\circ} 19^{\prime} \mathrm{N}, 3^{\circ} 19^{\prime} \mathrm{W}\right)$ in the middle of the Jarama river basin. The soil is a Typic Xerofluvent (Soil Survey Staff 1998), which is a sandy loam that becomes progressively more sandy with depth to a gravel layer located at $1.5-2.2 \mathrm{~m}$. The mean water-storage capacity of the soil profile $(0-2 \mathrm{~m})$ was estimated at $309 \pm 33 \mathrm{~mm}$, while that for the top $0.5 \mathrm{~m}$ was $154 \pm 21 \mathrm{~mm}$, as measured by time domain reflectometry. Some physicochemical characteristics of the top $0-50 \mathrm{~cm}$ are shown in Table 1. Other characteristics of the soil and the methods of soil analysis have been previously described (Díez et al. 2001). The water-table fluctuated from 4 to $4.5 \mathrm{~m}$ below the soil surface, depending on rainfall and river discharge. The highest temperatures at the Field Station during the maize crop were between 12 and $37^{\circ} \mathrm{C}$ in 1998,14 and $39^{\circ} \mathrm{C}$ in 1999 , and 14 and $37^{\circ} \mathrm{C}$ in 2001 , while the lowest temperatures were between 4 and $19^{\circ} \mathrm{C}$ in 1998,5 and $28^{\circ} \mathrm{C}$ in 1999 , and 4 and $21^{\circ} \mathrm{C}$ in 2001. The rainfall mean in the region is $460 \mathrm{~mm} \mathrm{yr}^{-1}$.

\section{Experimental design, field instrumentation and crops}

Maize was grown at the experimental site in 1998, 1999 and 2001. In 2000, however, barley was grown to avoid the problems caused by cultivating the same crop for too many consecutive seasons. Four treatments were applied each year to triplicate plots $(9.9 \times 11.1 \mathrm{~m})$ : an optimal rate of urea $(\mathrm{U})$, an optimal rate of pig slurry $(\mathrm{P} 1)$, a three times the optimal rate of pig slurry (P3), and a control with no $\mathrm{N}$

Table 1. Physicochemical characteristics of the sandy loam soil at $0-50 \mathrm{~cm}$ depth.

\begin{tabular}{lc}
\hline $\mathrm{pH}_{\mathrm{H}_{2} \mathrm{O}}$ & 8.1 \\
Organic matter $\left(\mathrm{g} \mathrm{kg}^{-1}\right)$ & 14.0 \\
$\mathrm{CaCO}_{3}\left(\mathrm{~g} \mathrm{~kg}^{-1}\right)$ & 34.0 \\
Bulk density $\left(\mathrm{t} \mathrm{m}^{-3}\right)$ & 1.47 \\
\hline
\end{tabular}

fertilizer (P0). Based on electro-ultrafiltration soil analysis (EUF) results and according to criteria established by Sánchez et al. (1998), the optimal $\mathrm{N}$ rates (Table 2) for the maize crop were 170,162 and $176 \mathrm{~kg} \mathrm{~N}^{-1}$ in 1998,1999 and 2001, respectively. For the barley in 2000, the optimal rate was $120 \mathrm{~kg} \mathrm{Nha}^{-1}$. These rates were lower than those applied by farmers from this area $\left(300 \mathrm{~kg} \mathrm{Nha}^{-1}\right.$ for maize and $150 \mathrm{~kg} \mathrm{Nha}^{-1}$ for barley). Optimal $\mathrm{N}$ rates (U and P1) were calculated using the expression:

$$
\begin{aligned}
\text { Optimal } \mathrm{N} \text { rate }= & (\mathrm{N} \text { uptake by aboveground crop } \\
& - \text { available soil } \mathrm{N}) / \mathrm{N} \text { efficiency }
\end{aligned}
$$

Where available, soil $\mathrm{N}$ was calculated by soil analysis before sowing (Sánchez et al. 1998). N efficiency had previously been estimated to be from 0.7 to 0.8 for this crop (Díez et al. 2000). The amount of pig slurry applied (Table 2) to the P1 plots was calculated considering the $\mathrm{N}$ content of pig slurry (Table 3).

The pig slurry was collected from differents farms each year at discharge points and kept in storage tanks. Table 3 shows the characteristics of representative slurry samples taken at regular intervals (every $5 \mathrm{~min}$ ) during application. A portion $(50 \mathrm{~mL})$ of each sample was first homogenized by shaking for $10 \mathrm{~min}$, then analysed following the protocol of Díez et al. (2001).

The slurry was applied to the soil through a band spreader connected to a tanker, following the local technique. Applications were made at the beginning of April for the

Table 2. Pig slurry applied to maize based on optimal $\mathrm{N}$ requirements in each year.

\begin{tabular}{lccc}
\hline & 1998 & 1999 & 2001 \\
\hline Available N $\left(\mathrm{kg} \mathrm{N} \mathrm{ha}^{-1}\right)^{\mathrm{a}}$ & 111 & 114 & 107 \\
Optimal rate N $\left(\mathrm{kg} \mathrm{N} \mathrm{ha}^{-1}\right)^{\mathrm{b}}$ & 170 & 162 & 176 \\
Slurry Kjeldahl N $\left(\mathrm{mg} \mathrm{N} \mathrm{L}^{-1}\right)$ & 3130 & 2700 & 4834 \\
Pig slurry rate $\left(\mathrm{m}^{3} \mathrm{ha}^{-1}\right)^{\mathrm{c}}$ & 54.3 & 60.0 & 35.2 \\
\hline
\end{tabular}

${ }^{a}$ Available $\mathrm{N}$ was calculated by means of soil analysis at $30 \mathrm{~cm}$ by the EUF method before sowing time, previously calibrated by $\mathrm{N}$ balance (Sánchez et al. 1998), which includes mineral $\mathrm{N}$ plus potentially mineralizeable $\mathrm{N}$.

${ }^{\mathrm{b}}$ Optimal $\mathrm{N}$ rates were calculated using the expression given in equation (1) (Sánchez et al. 1998).

${ }^{\mathrm{c}}$ values

These were obtained by calculating the quantity of pig slurry necessary to obtain the optimal $\mathrm{N}$ rate, considering the Kjeldahl-N content and available $\mathrm{N}$ in the soil.

\begin{tabular}{|c|c|c|c|}
\hline & 1998 & 1999 & 2001 \\
\hline Density $\left(\mathrm{g} \mathrm{L}^{-1}\right)$ & $1.02 \pm 0.002$ & $1.01 \pm 0.003$ & $1.02 \pm 0.002$ \\
\hline Dry matter $(\%)$ & $8.50 \pm 1.3$ & $0.56 \pm 0.4$ & $1.60 \pm 0.7$ \\
\hline Organic matter (\% DM) & $74.0 \pm 8.1$ & $60.4 \pm 6.5$ & $59.0 \pm 4.2$ \\
\hline Conductivity $\left(\mathrm{mS} \mathrm{cm}^{-1}\right)$ & $20.0 \pm 1.2$ & $6.4 \pm 0.7$ & $22.1 \pm 1.8$ \\
\hline $\mathrm{NO}_{3}^{-}-\mathrm{N}\left(\mathrm{mg} \mathrm{L}^{-1}\right)$ & $4.5 \pm 0.2$ & $1.6 \pm 0.1$ & $1.6 \pm 0.2$ \\
\hline $\mathrm{NH}_{4}^{+}-\mathrm{N}\left(\mathrm{mg} \mathrm{L}^{-1}\right)$ & $2264 \pm 34$ & $344 \pm 41$ & $3792 \pm 37$ \\
\hline Kjeldhal-N (mg N L $\left.{ }^{-1}\right)$ & $3130 \pm 28$ & $2700 \pm 31$ & $4834 \pm 38$ \\
\hline Organic-N (mg N L $\left.{ }^{-1}\right)$ & 862 & 2355 & 1040 \\
\hline $\mathrm{K}\left(\mathrm{mg} \mathrm{KL} \mathrm{L}^{-1}\right)$ & $2108 \pm 5$ & $294 \pm 8$ & $920 \pm 12$ \\
\hline$P\left(\mathrm{mg} \mathrm{NL}^{-1}\right)$ & $105 \pm 7$ & $164 \pm 8$ & $270 \pm 11$ \\
\hline $\mathrm{Na}\left(\mathrm{mg} \mathrm{L}^{-1}\right)$ & $304 \pm 9$ & $204 \pm 13$ & $330 \pm 18$ \\
\hline
\end{tabular}

Table 3. Physicochemical characteristics of pig slurry. ${ }^{a}$

${ }^{a}$ Values are given as means of 20 subsamples \pm standard deviation. 
maize crop. The soil was then worked with a rotocultivator to incorporate the slurry into the the soil $(0-5 \mathrm{~cm}) . \mathrm{P} 1$ and P3 doses were applied in one single application. The urea was incorporated in June.

After slurry application and ploughing, maize (Zea mays L. cv. Juanita) was sown at the end of April each year (1998, 1999 and 2001). The rows were $75 \mathrm{~cm}$ apart and the plant density 75000 plants $\mathrm{ha}^{-1}$. During seedbed preparation, superphosphate $\left(18 \% \mathrm{P}_{2} \mathrm{O}_{5}\right)$ and $\mathrm{K}_{2} \mathrm{SO}_{4}\left(50 \% \mathrm{~K}_{2} \mathrm{O}\right)$ were applied at $50 \mathrm{~kg} \mathrm{P}_{2} \mathrm{O}_{5} \mathrm{ha}^{-1}$ and $121 \mathrm{~kg} \mathrm{~K}_{2} \mathrm{O} \mathrm{ha}^{-1}$. The maize was cultivated following usual practices (including ploughing, weed-killer treatments, etc.), and was harvested in October when the grain was mature. Barley (Hordeum vulgare L. cv. Nevada) was sown in November 1999 at a density of $160 \mathrm{~kg} \mathrm{ha}^{-1}$. The crop was harvested on 20 June 2000.

The water used throughout the experiment was taken from an irrigation ditch from the Jarama River. This water was sampled 33 times. The mean quality components of the irrigation water were: $\mathrm{NO}_{3}^{-}, 5.1 \pm 0.5 \mathrm{mg} \mathrm{N} \mathrm{L}^{-1} ; \mathrm{Na}$, $90 \pm 16 \mathrm{mg} \mathrm{L}^{-1}$; total solids, $650 \pm 50 \mathrm{mg} \mathrm{L}^{-1}$; electrical conductivity (EC), $1.0 \pm 0.1 \mathrm{dS} \mathrm{m}^{-1}$; sodium adsorption ratio (SAR), 1.55 and $\mathrm{pH} 7.6 \pm 0.2$. The groundwater contained: $\mathrm{NO}_{3}^{-}, \quad 2.7 \pm 1.0 \mathrm{mg} \mathrm{NL}^{-1}$ and $\mathrm{Na}^{+}$, $70 \pm 25 \mathrm{mg} \mathrm{L}^{-1}$.

An overhead mobile-line sprinkler system was used to irrigate the crops. Irrigation started 5 days before the end of June and continued to the end of August. The maize was watered every 7-10 days following the schedule used by the majority growers in the area. (Some $70-80 \%$ of the water applied is used by the crop under these conditions.) Rainfall and total irrigation inputs are shown in Table 4. The quantity of applied irrigation was that recommended by the advisory services of the area, based on a potential evapotranspiration $\left(E T_{\mathrm{o}}\right)$ of $500-520 \mathrm{~mm}$ for the dry season (Instituto Técnico Agronómico Provincial 1998). Irrigation water was applied on seven occasions (mean $61 \mathrm{~mm}$ ) during the dry season of 1998, eight occasions (mean $69 \mathrm{~mm}$ ) in 1999 and eight (mean $77 \mathrm{~mm}$ ) in 2001.

\section{Sampling}

Samples of the soil solution from the ceramic cups were extracted 33 times throughout the experiment. A vacuum of $-80 \mathrm{kPa}$ was applied to the tubes and maintained for a period of 7-10 days. After this period, water samples were extracted using air pressure, and $\mathrm{NO}_{3}^{-}, \mathrm{Na}^{+}$and EC determined, the latter being measured to estimate salt concentration $\left(\mathrm{g} \mathrm{L}^{-1}\right)$ (Caballero et al. 2001).

Table 4. Water inputs, output and balance during the crop-growing periods.

\begin{tabular}{cccccc}
\hline Year & $\begin{array}{c}\text { Rainfall } \\
(\mathrm{mm})\end{array}$ & $\begin{array}{c}\text { Irrigation } \\
(\mathrm{mm})\end{array}$ & $\begin{array}{c}\text { Evapotranspiration } \\
(E T)^{\mathrm{a}}(\mathrm{mm})\end{array}$ & $\begin{array}{c}\text { Drainage }^{\mathrm{a}} \\
(\mathrm{mm})\end{array}$ & Water balance \\
\hline 1998 & 106.0 & 428 & 426 & 83 & 26 \\
1999 & 163.4 & 554 & 603 & 138 & -24 \\
2001 & 130.0 & 619 & 660 & 132 & -43 \\
\hline
\end{tabular}

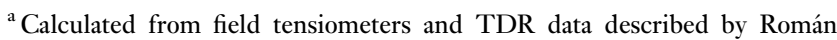
et al. (1996) based on water flow direction and water balance between layers.
For the salt leaching study, two ceramic cups were used in each plot to obtain soil solution samples at a depth of $1.4 \mathrm{~m}$ (Díez et al. 2001). It was assumed that water reaching this depth near the gravel layer would quickly leach into the groundwater (mean depth $4 \mathrm{~m}$ ) because of the high hydraulic conductivity (Smith \& Mullins 1991). During drainage periods, $\mathrm{NO}_{3}^{-}$and $\mathrm{Na}^{+}$leaching were calculated weekly by multiplying the weekly drainage by the corresponding $\mathrm{NO}_{3}^{-}$and $\mathrm{Na}^{+}$concentrations at $1.4 \mathrm{~m}$ at each sampling event (Díez et al. 1997). Errors in the estimation of drainage volume are discussed by Román et al. (1999). $\mathrm{NO}_{3}^{-}$concentration was determined using a Technicon AAII Autoanalyzer (Technicon Hispania) employing the $\mathrm{N} 1$ naphthylethylenediamine method, $\mathrm{Na}^{+}$was determined by atomic absorption spectrophotometry (Perkin-Elmer 403, Perkin-Elmer Hispania), and EC by a Crison 525 conductivity meter.

Plants were harvested from $5 \mathrm{~m}$ of two adjacent rows in the middle of each plot and their aboveground biomass determined. Ten of the harvested plants were randomly selected. The stalk, leaves, bracts, cob and grain were separated and weighed, oven-dried for $24 \mathrm{~h}$ at $60^{\circ} \mathrm{C}$ followed by a further $2 \mathrm{~h}$ at $80^{\circ} \mathrm{C}$, and weighed again to determine their dry matter (DM) content. The harvest index (HI) was calculated as the grain weight over the aboveground biomass (percentage). Grain yield $\left(\mathrm{kg} \mathrm{ha}^{-1}\right)$ was calculated and plant $\mathrm{N}$ content determined as described in Díez et al. (2001).

\section{Monitoring soil mater content, hydraulic head and drainage}

Time domain reflectometry (TDR) probes (at a maximum depth of $2 \mathrm{~m}$ ) and vertical tensiometers (capable of measuring water pressures of $0-80 \mathrm{kPa}$ ) were installed according to the method described by Díez et al. (2001) in the four central plots of the 12 used in the experiment. Soil water potential gradients (the relationship between the hydraulic head $[h]$ and the soil depth) were used to determine water movement through the soil. Four water flow patterns were identified during the course of the work, and six patterns of water-balance partitioning were reported (see Román et al. 1996). Water storage, estimated from the volumetric water content $(\theta$, TDR), and the hydraulic head were determined before and after each irrigation session during growth periods. Data provided by the instruments in the middle four plots plus the water flow direction and water balance in each soil layer (Table 4) were used to calculate the drainage $(D)$ and evapotranspiration $(E T)$ rate of each plot weekly during the growing season, according to the method of Roman et al. (1996). Each of the 12 plots was provided with four extraction tubes $(63 \mathrm{~mm}$ i.d.; one at a depth of $0.5 \mathrm{~m}$, one at $0.9 \mathrm{~m}$, and two at $1.4 \mathrm{~m}$ ) attached to porous ceramic cups to collect soil solution samples.

\section{Statistical analysis}

Statistical analysis was performed using Statgraphics PLUS 5.1 software (Manugistics 2000). Analysis of variance, according multivariate models, was used to study the differences between data sets, agronomic data (plant dry matter at harvest, grain yield and plant $\mathrm{N}$ content) and soil solution data (EC, $\mathrm{NO}_{3}^{-}$and $\mathrm{Na}^{+}$concentrations). Differences between treatments and soil depths were analysed and 
compared using the Duncan Test. Significance was set at $P<0.05$.

\section{RESULTS AND DISCUSSION}

The physicochemical characteristics (Table 3) of the slurries showed great variability between years, especially in dry matter (from 0.56 to $8.50 \%$ ) due to different storage systems (pit in 1998 and lagoon in 1999 and 2001), $\mathrm{NH}_{4}^{+}-\mathrm{N}$ (from 0.34 to $3.7 \mathrm{~g} \mathrm{~L}^{-1}$ ), Kjeldahl-N (from 2.70 to $4.83 \mathrm{~g} \mathrm{~L}^{-1}$ ), $\mathrm{NO}_{3}^{-}-\mathrm{N}$ (from 1.6 to $4.5 \mathrm{mg} \mathrm{L}^{-1}$ ), and organic$\mathrm{N}$ (from 0.86 to $2.35 \mathrm{~g} \mathrm{~L}^{-1}$ ). Since the application rate was calculated taking into account the available $\mathrm{N}$ content of the soil, the $\mathrm{N}$ content of the slurries and the amount of $\mathrm{N}$ needed by the crop, the volumes applied were different each year (Table 2).

\section{Nitrate leaching}

Amounts of between 428 and $619 \mathrm{~mm}$ of irrigation water were applied to the maize, depending on the soil water reserve (Table 4). Mean drainage losses were 82, 138 and $131 \mathrm{~mm}$ during 1998, 1999 and 2001, respectively, representing an overall mean drainage loss of $22 \%$ of the irrigation water applied (Table 4). Drainage during the barley crop was low $(33 \mathrm{~mm})$ because it was not irrigated. However, drainage for the entire year of 2000 was $204 \mathrm{~mm}$ due to autumn (post-barley crop) rainfall.

Table 5 shows that soil solution $\mathrm{NO}_{3}^{-}$concentrations increased significantly with increasing $\mathrm{N}$ application, regardless of $\mathrm{N}$ source. $\mathrm{N}$ concentrations were similar at a depth of $50 \mathrm{~cm}$ in the $\mathrm{U}$ and $\mathrm{P} 1$ treatments where the total $\mathrm{N}$ applied was the same. Over the course of the experiment there were no appreciable changes in $\mathrm{NO}_{3}^{-}$concentration between the drainage (after rainfall and irrigation) and non-drainage periods. Great spatial variability in $\mathrm{NO}_{3}^{-}$ concentrations was observed between samplings of each plot and also between plots, confirming the results of Kengni et al. (1994), Bruckler et al. (1997) and Díez et al. (2001) (Table 4).

Nitrate concentrations of the soil solution at $1.4 \mathrm{~m}$ (Table 5) were used to study the possibility of groundwater contamination. Cumulative $\mathrm{NO}_{3}^{-}$discharge at $1.4 \mathrm{~m}$

Table 5. Mean nitrate concentration ${ }^{\mathrm{a}}$ of the soil solution at $0.5,0.9$ and $1.4 \mathrm{~m}$ depth given as cumulative values for different treatments for the duration of the experiment (1998, 1999 and 2001).

\begin{tabular}{lccccc}
\hline $\begin{array}{l}\text { Soil depth } \\
(\mathrm{m})\end{array}$ & \multicolumn{5}{c}{ Nitrate concentration $\left(\mathrm{mg} \mathrm{NO}_{3}^{-}-\mathrm{NL}^{-1}\right)^{\mathrm{a}}$} \\
\cline { 2 - 6 } & ANOVA & \multicolumn{1}{c}{$\mathrm{P} 0^{\mathrm{b}}$} & $\mathrm{U}$ & $\mathrm{P} 1$ & $\mathrm{P} 3$ \\
\hline 0.5 & $F=21.06$ & $41 \pm 53 \mathrm{a}$ & $92 \pm 59 \mathrm{~b}$ & $102 \pm 62 \mathrm{~b}$ & $258 \pm 174 \mathrm{c}$ \\
& $P=0.001$ & & & & \\
0.9 & $F=23.90$ & $57 \pm 47 \mathrm{a}$ & $181 \pm 91 \mathrm{~b}$ & $87 \pm 47 \mathrm{a}$ & $172 \pm 101 \mathrm{~b}$ \\
& $P=0.001$ & & & & \\
1.4 & $F=69.03$ & $64 \pm 31 \mathrm{a}$ & $147 \pm 61 \mathrm{~b}$ & $180 \pm 98 \mathrm{~b}$ & $258 \pm 95 \mathrm{c}$ \\
& $P=0.001$ & & & &
\end{tabular}

${ }^{\mathrm{a}}$ Data based on six replicate ceramic cup extractions at $1.4 \mathrm{~m}$ depth $(2 \times$ plot $)$ per fertilizer treatment and three replicate at 0.5 and $0.9 \mathrm{~m}$ depth per fertilizer treatment (33 samplings over the three growing seasons). Mean followed by standard deviation; different small letters for each row indicate significant differences between treatments $(P<0.05$, Duncan test).

${ }^{\mathrm{b}}$ For treatment key, see Materials and Methods. depended mainly on the irrigation water applied and the fertilizer treatment used (Figure 1). As observed by Díez et al. (2000), total leaching depended mainly on drainage and less on variations in $\mathrm{NO}_{3}^{-}$concentration at the percolation depth. Significant differences $(P<0.05)$ between treatments were recorded in the cumulative $\mathrm{NO}_{3}^{-}$leaching over the whole experimental period, with losses of 329 , 215,173 and $78 \mathrm{~kg} \mathrm{~N}^{-1}$ for P3, P1, U and P0 treatments, respectively. The influence of pig slurry rate was large: the $\mathrm{N}$ loss induced at the triple rate $(\mathrm{P} 3)$ was twice that at the single rate ( $\mathrm{P} 1)$. The proportional $\mathrm{N}$ losses due to leaching, expressed as a percentage of $\mathrm{N}$ applied in slurry fertilizer (discounting the $\mathrm{N}$ leached in the control), were 18, 27 and $21 \%$ for the P3, P1 and $\mathrm{U}$ treatments, respectively.

\section{Changes in soil salinity}

Before the first application of the slurry, the mean soil solution ECs were 3.07, 2.86 and $4.20 \mathrm{dS} \mathrm{m}^{-1}$ at 50,90 and $140 \mathrm{~cm}$ depth, respectively. The amount of soluble salts expressed as total dissolved salts (TDS) was calculated using the equation proposed by Caballero et al. (2001) obtained from data of a previous experiment performed in the same soil.

$$
\begin{aligned}
& \operatorname{TDS}\left(\mathrm{g} \mathrm{L}^{-1}\right)=8.887 \text { EC }\left(\mathrm{S} \mathrm{m}^{-1}\right)+0.135 \\
& \quad\left(r^{2}=0.885 ; n=464\right)
\end{aligned}
$$

Soil salinity in the pig slurry plots indicated by EC values increased significantly between 1998 and 2001 (2019 and $6058 \mathrm{~kg} \mathrm{TDS} \mathrm{ha}^{-1}$ for the P1 and P3 treatments, respectively). Electrical conductivity in the soil solution also increased with soil depth (Figure 2), since salt is highly mobile under conditions of irrigation and high soil permeability. Owing to the root depth for maize in this soil $(70-80 \mathrm{~cm})$, the movement of water, and consequently salts, was always downward at depths of $80-140 \mathrm{~cm}$. These results are consistent with those of Hao \& Chang (2003), who studied the use of cattle manure.

Figure 3 shows the cumulative curves for the leached TDS. Significant differences between P1 and P3 $(P<0.05)$ were recorded in the cumulative TDS leached over the whole experimental period, with losses of 37.5 , 28.1 and $25.8 \mathrm{tha}^{-1}$ for the P3, P1 and P0 treatments, respectively. The increases in TDS losses over the control

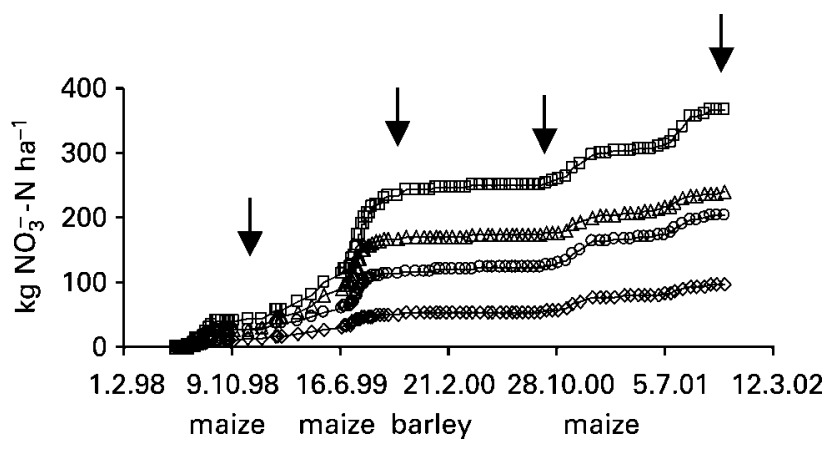

Figure 1. Cumulative nitrate losses by leaching at a soil depth of $1.4 \mathrm{~m}$ during the experiment. $\diamond=$ control treatment (no slurry) (P0); $\bigcirc=$ urea treatment $(\mathrm{U}) ; \Delta=$ optimal $\mathrm{N}$ rate of pig slurry treatment $(\mathrm{P} 1) ; \square=$ three times the optimal $\mathrm{N}$ rate of pig slurry $(\mathrm{P} 3)$. Arrows indicate harvest date. 
EC $50 \mathrm{~cm}$ depth
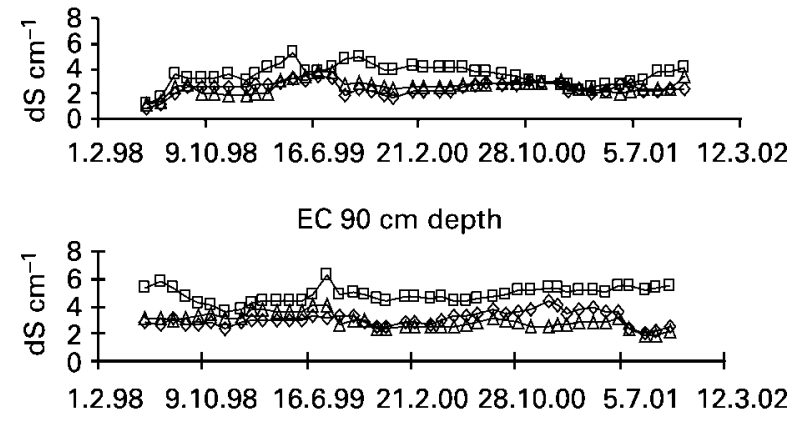

EC $140 \mathrm{~cm}$ depth

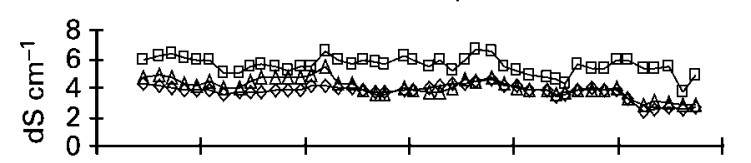

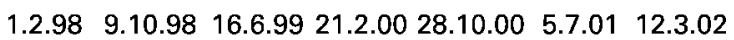
Date

Figure 2. Electrical conductivity (EC) in soil solution at 50, 90 and $140 \mathrm{~cm}$ depth during the experiment. $\diamond=$ control treatment (no slurry) (P0); $\Delta=$ optimal $\mathrm{N}$ rate of pig slurry treatment (P1); $\square=$ three times the optimal $\mathrm{N}$ rate of pig slurry $(\mathrm{P} 3)$.

caused by pig slurry were 2030 and $7437 \mathrm{~kg} \mathrm{ha}^{-1}$ for the P1 and P3 treatments, respectively (Table 6). These amounts are similar to the quantities of salt added. However, this coincidence was not clear in the annual balance, since some of the salts added during 1998 and 1999 were leached in 2001. Heavy rainfall during the summer after the barley harvest (August and September 2000) accelerated the leaching of salts accumulated in the soil during the cultivation of the preceding maize crop (Figure 3). These results confirm those of Bustos et al. (1996), who concluded that the salts accumulated in the soil during the maize growth season in a Mediterranean climate might leach into the groundwater after harvest, thereby intensifying the risk of groundwater pollution.

Increases in soil salinity were associated with changes in $\mathrm{Na}^{+}$concentration (Figure 4), reflecting the amount of sodium added over the entire experimental period (52 and $157 \mathrm{~kg} \mathrm{Na} \mathrm{ha}^{+1}$ with $\mathrm{P} 1$ and $\mathrm{P} 3$ treatments, respectively). The soil solution $\mathrm{Na}^{+}$concentration correlated significantly with EC values in the P3 treatment at a depth of $140 \mathrm{~cm}$ $(r=0.488 ; P<0.001)$.

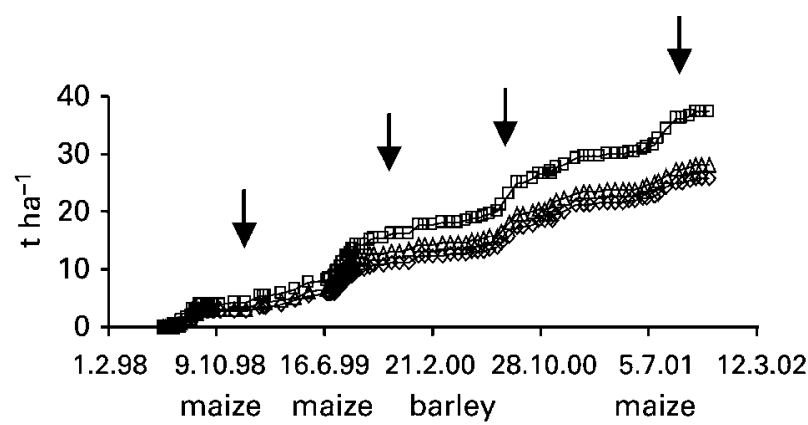

Figure 3. Cumulative TDS (total dissolved salts) losses by leaching to groundwater during the experiment. $\diamond=$ control treatment (no slurry) (P0); $\Delta=$ optimal $\mathrm{N}$ rate of pig slurry treatment $(\mathrm{P} 1) ; \square=$ three times the optimal $\mathrm{N}$ rate of pig slurry (P3). Arrows indicate harvest date.
Table 6. Total dissolved salts balance as influenced by pig slurry applied.

\begin{tabular}{lccccc}
\hline & 1988 & 1999 & 2001 & Total \\
\hline EC $\left(\mathrm{S} \mathrm{m}^{-1}\right)$ pig slurry & & 2.00 & 0.64 & 2.21 & \\
Pig slurry rate P1 $\left(\mathrm{m}^{3} \mathrm{ha}^{-1}\right)$ & & 54.3 & 60.0 & 35.2 & \\
TDS added $\left(\mathrm{g} \mathrm{L}^{-1}\right)$ & & 17.90 & 5.85 & 19.77 & \\
Soluble salts added $\left(\mathrm{kg} \mathrm{ha}^{-1}\right)$ & $\mathrm{P} 1$ & 972 & 351 & 695 & 2019 \\
& $\mathrm{P} 3$ & 2917 & 1053 & 2087 & 6058 \\
& $\mathrm{P}^{\mathrm{b}}$ & 401 & 1420 & 209 & 2030 \\
& $\mathrm{P3}^{\mathrm{c}}$ & 1379 & 2830 & 3228 & 7437 \\
\hline
\end{tabular}

${ }^{\mathrm{a}} \mathrm{TDS}=$ total dissolved salts. These values were calculated from equation (2) (Caballero et al. 2001); ${ }^{\mathrm{b}}$ TDS.P1 - TDS.P0; ${ }^{\mathrm{c}}$ TDS.P3 - TDS.P0.

Large rates of slurry accentuate the problem of groundwater salinization and nitrate pollution, so much less than $200 \mathrm{~m}^{3} \mathrm{ha}^{-1} \mathrm{yr}^{-1}$, as was proposed by Bernal et al. (1992) for a similar soil, should be applied. In this work, the optimal $\mathrm{P} 1$ treatment rate was $35-55 \mathrm{~m}^{3} \mathrm{ha}^{-1} \mathrm{yr}^{-1}$, depending on soil $\mathrm{N}$ content, slurry $\mathrm{N}$ content and crop $\mathrm{N}$ requirements.

The analysis of variance for each treatment corresponding to $\mathrm{Na}^{+}$concentration of the soil solution at $1.4 \mathrm{~m}$ depth during the experiment is shown in Table 7. The mean soil solution $\mathrm{Na}^{+}$concentration for the experimental period was less in the $\mathrm{U}$ treatment $\left(184,265\right.$ and $342 \mathrm{mg} \mathrm{Na} \mathrm{L}^{-1}$ at 50,90 and $140 \mathrm{~cm}$ depth, respectively) than in the corresponding control treatments $\left(207,339\right.$ and $\left.412 \mathrm{mg} \mathrm{Na} \mathrm{L}^{-1}\right)$ because more salts were taken up by the urea-treated crops.

$N$ uptake and grain yield

Significant differences $(P<0.05)$ were detected between the different treatments with respect to dry matter, plant $\mathrm{N}$ uptake and grain yield in both the 1998 and 2001 maize crops (Table 8). However, in 1999 only the crop N uptake in the control differed from the other treatments. Grain yield differences between P1 and P3 treatments were only observed in 1998. The application of high slurry rates
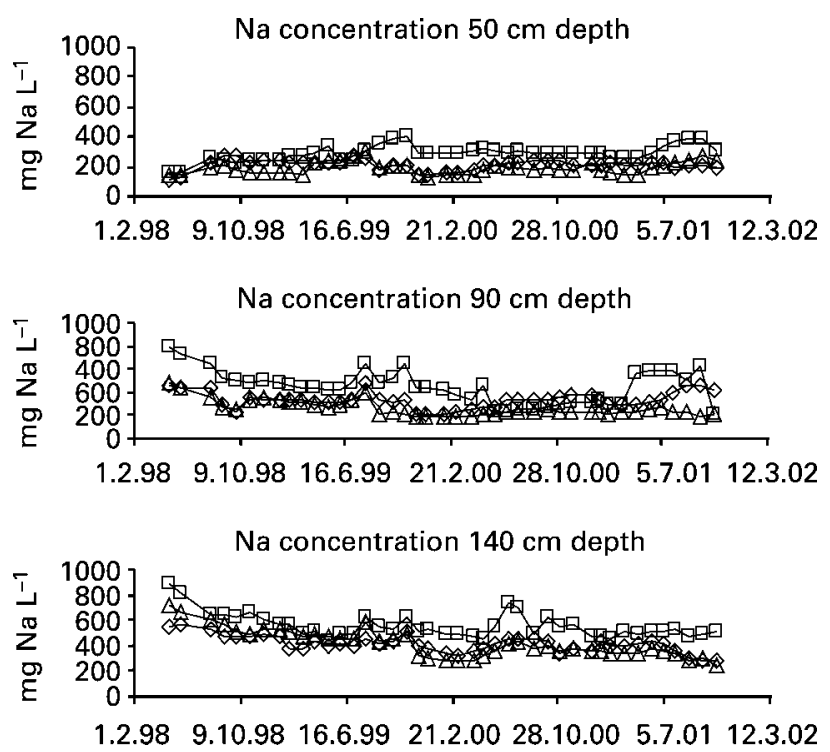

Figure $4 . \mathrm{Na}^{+}$concentration in soil solution at 50,90 and $140 \mathrm{~cm}$ depth, during the experiment. $\diamond=$ control treatment (no slurry) $(\mathrm{P} 0) ; \Delta=$ optimal $\mathrm{N}$ rate of pig slurry treatment $(\mathrm{P} 1) ; \square=$ three times the optimal $\mathrm{N}$ rate of pig slurry $(\mathrm{P} 3)$. 
Table 7. Mean Na concentration of the soil solution at $1.4 \mathrm{~m}$ soil depth given as cumulative values for different treatments for the duration of the experiment (1998, 1999 and 2001).

\begin{tabular}{lccccc}
\hline $\begin{array}{l}\text { Soil } \\
\text { depth } \\
(\mathrm{m})\end{array}$ & \multicolumn{5}{c}{ Sodium concentration $\left(\mathrm{mg} \mathrm{Na} \mathrm{L}^{-1}\right)^{\mathrm{a}}$} \\
\cline { 2 - 6 } & ANOVA & $\mathrm{P}^{\mathrm{b}}$ & $\mathrm{U}$ & $\mathrm{P} 1$ & $\mathrm{P} 3$ \\
\hline 1.4 & $F=170.59$ & $412 \pm 120 \mathrm{~b}$ & $342 \pm 114$ a & $508 \pm 143 \mathrm{c}$ & $658 \pm 231 \mathrm{~d}$ \\
1.4 & $P=0.001$ & & & & \\
\hline
\end{tabular}

${ }^{\mathrm{a} D a t a}$ based on six replicate ceramic cup extractions at $1.4 \mathrm{~m}$ depth $(2 \times$ plot $)$ per fertilizer treatment $(33$ samplings over the three growing seasons). Mean followed by standard deviation; different small letters for each row indicate significant differences between treatments $(P<0.05$, Duncan Test). ${ }^{b}$ For treatment key, see Materials and Methods.

Table 8. Effect of application of increasing rate of pig slurry and urea fertilizer on dry matter, $\mathrm{N}$ uptake and yield of maize in the three growing seasons. ${ }^{a}$

\begin{tabular}{ccccc}
\hline Year & Treatments $^{\mathrm{b}}$ & $\begin{array}{c}\text { Dry matter } \\
\left(\mathrm{kg} \mathrm{ha}^{-1}\right)\end{array}$ & $\begin{array}{c}\text { Plant N uptake } \\
\left(\mathrm{kg} \mathrm{ha}^{-1}\right)\end{array}$ & $\begin{array}{c}\text { Grain yield } \\
\left(\mathrm{kg} \mathrm{ha}^{-1}\right)\end{array}$ \\
\hline 1998 & P0 & $20930 \mathrm{ab}$ & $171 \mathrm{a}$ & $12824 \mathrm{a}$ \\
& $\mathrm{U}$ & $20321 \mathrm{a}$ & $171 \mathrm{a}$ & $12827 \mathrm{a}$ \\
& P1 & $21566 \mathrm{~b}$ & $230 \mathrm{ab}$ & $13523 \mathrm{a}$ \\
& P3 & $23951 \mathrm{c}$ & $241 \mathrm{~b}$ & $15460 \mathrm{~b}$ \\
& $P$ & 0.0001 & 0.0460 & 0.0014 \\
\hline 1999 & P0 & $17865 \mathrm{a}$ & $139 \mathrm{a}$ & $12445 \mathrm{a}$ \\
& U & $19327 \mathrm{a}$ & $196 \mathrm{~b}$ & $13359 \mathrm{a}$ \\
& P1 & $19580 \mathrm{a}$ & $198 \mathrm{~b}$ & $13682 \mathrm{a}$ \\
& P3 & $20152 \mathrm{a}$ & $199 \mathrm{~b}$ & $13938 \mathrm{a}$ \\
& $P$ & $0.098 \mathrm{NS}$ & 0.0020 & $0.2630 \mathrm{NS}$ \\
\hline 2001 & P0 & $17894 \mathrm{a}$ & $45 \mathrm{a}$ & $2820 \mathrm{a}$ \\
& U & $24386 \mathrm{~b}$ & $127 \mathrm{~b}$ & $6205 \mathrm{~b}$ \\
& P1 & $24313 \mathrm{~b}$ & $118 \mathrm{~b}$ & $5748 \mathrm{~b}$ \\
& P3 & $25161 \mathrm{~b}$ & $147 \mathrm{c}$ & $6485 \mathrm{bc}$ \\
& $P$ & 0.015 & 0.001 & 0.020 \\
\hline
\end{tabular}

${ }^{\text {a Different small letters in a column for each year indicate significant }}$ differences between treatments $(P<0.05$, Duncan Test $) \quad(P>0.05$ denotes not significant NS).

therefore appears to increase plant $\mathrm{N}$ uptake without increasing grain production, which confirms the results of Díez et al. (2001).

\section{CONCLUSIONS}

The results of this study indicate that application rates of pig slurry that are larger than optimal have little or no effect on crop yield, but they do increase soil salinization and nitrate pollution of water. The increases in TDS losses over the control caused by pig slurry were 2030 and $7437 \mathrm{~kg} \mathrm{ha}^{-1}$ for the $\mathrm{P} 1$ and $\mathrm{P} 3$ treatments, respectively, during the experiment. The salt concentration of the soil solution generally increased with profile depth and increasing slurry application. Calculating optimal slurry rates, taking into account their $\mathrm{N}$ content, the available soil $\mathrm{N}$ and crop requirements, is an effective way to reduce these risks.

\section{ACKNOWLEDGEMENTS}

This work was funded by the INIA (Spanish Ministry of Agriculture, Fisheries and Food Resources) for funding via
Project SC 98-C2.2. We thank M.D. Atienza for technical assistance.

\section{REFERENCES}

Al-Kaisi MM \& Waskom RM 2002. Utilizing swine effluent for sprinklerirrigated corn production. Journal of Soil Water Conservation 57(2), $111-120$.

Bernal MP Roig A Madrid R \& Navarro AF 1992. Salinity risk on calcareous soils following pig slurry applications. Soil Use and Management $9,125-129$.

Bruckler L de Cockborn AM Renault P \& Claudot B 1997. Spatial and temporal variability of nitrate in irrigated salad crops. Irrigation Science $17,53-61$.

Bustos A Román R Caballero R Díez JA Cartagena MC Vallejo A \& Caballero A 1996. Water and solute movement under conventional maize in Central Spain. II. Salt leaching. Soil Science Society of America Journal 60, 1536-1540.

Caballero R Bustos A \& Román R 2001. Soil salinity under traditional and improved irrigation schedules in central Spain. Soil Science Society of America Journal 65, 1210-1218.

Chávez ER \& Babot D 2001. Implicaciones medioambientales asociadas al desarrollo acelerado de la producción porcina en España. Anaporc 208, 75-89

Díez JA Román R Caballero R \& Caballero A 1997. Nitrate leaching from soils under a maize-wheat-maize sequence, two irrigation schedules and three types of fertilisers. Agriculture, Ecosystem and Environment $65,189-199$

Díez JA Caballero R Román R Tarquis A Cartagena MC \& Vallejo A 2000. Integrated fertiliser and irrigation management to reduce nitrate leaching in Central Spain. Journal of Environmental Quality 29, 1539-1547.

Díez JA de la Torre AI Cartagena MC Carballo M Vallejo A \& Muñoz MJ 2001. Evaluation of the application of pig slurry to an experimental crop using agronomic and ecotoxicological approaches. Journal of Environmental Quality 30, 2165-2172.

European Community 1991. Directive of Nitrate Pollution in Agriculture. EC 91/676. Office for Official Publications of the European Community L-2985 Luxembourg pp 1-8.

European Community 2001. Pollutants in urban waste water and sewage sludge. Office for Official Publications of the European Community L-2985 Luxembourg 244 pp.

Ferrer PJ \& Sanz JB 1983. Posibilidades de utilización agrícola del estiércol liquido porcino (ELP) en relación a su valor fertilizante y su incidencia sobre el suelo. Composición y valor fertilizante del ELP. Anales INIA, Serie Agrícola 23, 35-57.

Hao X \& Chang C 2003. Does long-term heavy cattle manure application increase salinity of a clay loam soil in semi-arid southern Alberta? Agriculture Ecosystem and Environment 94, 89-103.

Instituto Técnico Agronómico Provincial. Diputación de Albacete. 1998 Boletin ITAP. Servicio de Asesoramiento de Riegos Albacete Spain.

Join Research Centre 2001. Trace element and organic matter contents of European soils: first results of the second phase of the 'short term action'. Joint Research Centre. Institut for Environment and Sustainability Ispra Italy. Soil and Waste Unit. Progress Report 29 pp.

Kengni L Vachaud G Thony JL Laty R Garino B Casabianca H Jame P \& Viscogliosi R 1994. Field measurements of water and nitrogen losses under irrigated maize. Journal of Hydrology 162, 23-46.

Manugistics 2000. StatgRaphic Plus Version 5.1. Manugistics Rockville MD USA.

Román R Caballero R Bustos A Díez JA Cartagena MC Vallejo A \& Caballero A 1996. Water and solutes movement under conventional maize in central Spain. I. Water balance. Soil Science Society of America Journal $60,1530-1536$

Román R Caballero R \& Bustos A 1999. Field water drainage under traditional and improved irrigation schedules for corn in Central Spain. Soil Science Society of America Journal 63, 1811-1817.

Sánchez L Díez JA Vallejo A Cartagena MC \& Polo A 1998. Estimate of mineralized organic nitrogen in soils using nitrogen balances and determining available nitrogen by the electroultrafiltration technique. Journal of Agricultural and Food Chemistry 46, 2036-2043. 
Shortall JG \& Liebhardt WC 1975. Yield and growth of corn as affected by poultry manure. Journal of Environmental Quality 4, $186-191$.

Smith KA \& Mullins CE, eds 1991. Soil analysis. Physical methods. Marcel Dekker New York NY USA.

Soil Survey Staff 1998. Keys to Soil Taxonomy, 8th edn. Natural Resources Conservation Service USDA Washington DC USA.
Vinten AJA Lewis DR Fenlon DR Leach KA Howard R Svoboda I \& Ogden I 2002. Fate of E. coli and E. coli $\mathrm{O} 1527$ in soils and drainage water following cattle slurry application at 3 sites in southern Scotland. Soil Use and Management 18, 223-231.

Received March 2004, accepted after revisions September 2004. 